\title{
МАТЕРІАЛЬНЕ СТАНОВИЩЕ СТУДЕНТСТВА ПЕДАГОГІЧНИХ ТЕХНІКУМІВ НАЦІОНАЛЬНИХ МЕНШИН УСРР У 20-30-TI PP. ХХ СТ.
}

\author{
О. Б. Комарніцький
}

\begin{abstract}
Комарніцький $O$. Б. Матеріальне становище студентства педагогічних технікумів національних меншин УСРP у 20-30-ті pp. ХХ ст. У статті автор доводить, що у 20-30-ті pp. XX ст. для більшості педтехнікумів були характерними нестача навчальних приміщень, гуртожитків, насамперед у 1920-ті рр., що пояснювалося повоєнною руїною. Йдеться про забезпеченнячастини студентів стипендіями, розмір яких був мізерний. Молодь педтехнікумів нацменшин, яка прибувала на навчання з різних регіонів, особливо ії потребували. Автор зазначає, що студенти цих закладів мали краще стипендіальне забезпечення, ніж студенти українських педтехнікумів. У статті розповідається про запровадження плати за навчання, що погіршило матеріальне становище майбутніх педагогів. Чимало труднощів виникало із забезпеченням студентства харчуванням, особливо під час голодомоpy $1932-1933 \mathrm{pp}$.
\end{abstract}

Ключові слова: студент; технікум; гуртожиток; стипендія; харчування.

Комарницкий $A$. Б. Материальное положение студенчества педагогических техникумов национальных меньшинств УССР в 20-30-е гг. XX в. В статье автор доказывает, что в 20-30-е гг. $\mathrm{XX}$ в. для большинства педтехникумов были характерны нехватка учебных помещений, общежитий, прежде всего, в 1920-е гг., что объяснялось послевоенной разрухой. Речь идет об обеспечении части студентов стипендиями, размер которых был мизерным. Молодежь педтехникумов нацменьшинств, которая прибывала на обучение из разных регионов, особенно в ней нуждалась. Автор отмечает, что студенты этих заведений имели лучшее стипендиальное обеспечение, чем студенты украинских педтехникумов. В статье рассказывается о внедрении платы за обучение, что ухудшило материальное положение будущих педагогов. Большие трудности возникали с обеспечением студенчества питанием, особенно во время голодомора 1932-1933 гг.

Ключевые слова: студент, техникум, общежитие, стипендия, питание.

Komarnitsky A. B. The material situation of the Students in the Pedagogical Technical Schools of the National Minorities of the USSR in the 20-30s of the $20^{\text {th }}$ century. In the article the author proves that in the 20-30s of the $20^{\text {th }}$ century for the majority of pedagogical schools was a shortage of educational premises and dormitories, first of all, in the $1920 \mathrm{~s}$, which was explained by the post-war ruin. It is a question of providing part of the students with scholarships that were scanty. The youth of the pedtechnics of national minorities, who came to study from different regions, especially needed it. The author notes that the students of these institutions had the best scholarship than the students of Ukrainian pedagogical schools. The article talks about the introduction of tuition fees, which has worsened the material position of future teachers. Great difficulties arose with the provision of nutrition to students, especially during the Holodomor of 1932-1933.

Keywords: student; technical school; dormitory; scholarship; nutrition.

Для 20-30-х pp. XX ст. характерним було важке матеріальне становище студентів, більшість яких змушені були самі себе забезпечувати всім необхідним. Державна підтримка була мізерною, оскільки основні сили та кошти спрямовувалися на становлення економічного потенціалу країни.

Певною мірою це стосується і молоді педагогічних технікумів (далі - ПТ), які у 1920-ті pр. поряд з IHО надавали вищу освіту. Вони були створені відповідно до постанови РНК УСРР від 9 липня 1925 р. на базі вищих трирічних педагогічних курсів. 25 вересня 1929 р. постановою РНК УСРР їх перевели у розряд середніх навчальних закладів ${ }^{1}$. Серед педтехнікумів працювали і технікуми національних меншин. Наприкінці 20-х рр. підготовку фахівців для шкіл нацменшин проводили Вінницький, Житомирський, Київський та Одеський єврейські, Пришибський і Хортицький німецькі, Дніпропетровський i Київський російські, Київський польський, Преславський болгарський педтехнікуми. У 1930-х рр. було створено Нововітебський єврейський, Проскурівський польський і Маріупольський грецький педтехнікуми. 
Проблема матеріального становища молоді педтехнікумів нацменшин комплексно не досліджувалася. Деякі факти, які свідчать про матеріальне становище студентства цих закладів, містяться у працях В. Липинського ${ }^{2}$, О. Рябченко ${ }^{3}$, Б. Чирка ${ }^{4}$, Г. Шевчука ${ }^{5}$, А. Гринька $^{6}$, I. Міщенко 7 У статті на основі, насамперед, архівних джерел та матеріалів тогочасної періодики покажемо стан забезпечення студентів педтехнікумів нацменшин навчальними приміщеннями, житловою площею, стипендіями і харчуванням.

Особливо скрутним було становище майбутньої інтелігенції на початку 1920-х pp. Радянський історик Г. Шевчук писав: «Студенти 1920 і 1921 років винесли на своїх плечах «роки бурі і натиску», пройшовши школу війни і підпілля, надзвичайно виносливі, пристосовані до життя в колективі, уміють жити й працювати в умовах шуму в гуртожитках, на куточку стола, в нетопленій кімнаті, де доводиться спати, часто навіть не повечерявши... Прагнення до знання, гідна подиву виносливість, працездатність і самовідданість - основні риси студента-пролетаря» ${ }^{8}$. Значною мірою це було пов язаноз обмеженістю державного бюджету, повоєнною економічною руїною, загальним зубожінням населення. Асигнованих державою мізерних коштів було недостатньо.

Для більшості педвишів були характерними нестача навчальних приміщень, що ускладнювало навчальну діяльність студентів, наприклад, у Вінницькому єврейському ПТ ${ }^{9}$. На його базі відбувалися також заняття на короткотермінових курсах підготовки і перепідготовки учителів молодшого концентру. Навчання відбувалося переважно влітку, що заважало закладу проводити у приміщеннях ремонтні роботи і якісно підготуватися до нового навчального року ${ }^{10}$.

Досить складно було забезпечити студентів житлом, особливо в 1920-ті рр. Житловий фонд багатьох міст України був бідним, значною мірою пошкоджений у драматичні 1917 1921 рр. Все це створювало величезні труднощі у забезпечені молоді житловою площею.

Особливо критичним було становище 3 наданням житла у перші роки десятиліття. Більшість вишів не мали власних гуртожитків. Тому значна кількість студентів змушені були жити у родичів чи знімати кімнати у приватних осіб, що, звісно, вимагало чималих коштів. Так, у Вінницькому єврейському ПТ 1928 р. в інтернатах проживали лише 41,4\% Житомирському єврейському - в тому ж році $-51,8 \%{ }^{12}$. Значні проблеми із забезпеченням молоді житловою площею відчував Київський польський ПТ. У 1928-1929 н.р. в інтернаті площею 252 саж. на 1 студента в середньому припадало 0,7 саж. ${ }^{13}$.

Студентів поселяли також у будинках пролетарського студентства. На жаль, даних про проживання в них молоді педтехнікумів нацменшин нам віднайти не вдалося.

Труднощі виникали із забезпеченням студентських гуртожитків меблями, постільною білизною, зокрема у Харківському єврейському ПТ ${ }^{14}$. Цікаво, що 27 лютого 1928 р. на розширеному засіданні правління Житомирського єврейського ПТ одним із недоліків інтернату визнали відсутність коридорної системи. На цей закид цілком резонно відреагував член цього органу Преступа: «Говорити про коридорну систему в наших умовах рівносильно тому, щоби говорити про м'яку мебель в інтернаті. Насамперед потрібно потурбуватися, щоби кожний студент мав одіяло і змінну постільну білизну» ${ }^{15}$.

З 1929-1930 н. р. в Україні розгорнулося капітальне будівництво гуртожитків. Незважаючи на низку проблем, пов язаних із забезпеченням молоді житлом, поступово вони вирішувалися. Повністю забезпечили гуртожитками молодь Дніпропетровського російського ПТ ${ }^{16}$. У Проскурівському польському ПТ у вересні 1934 р. в гуртожитках мешкали

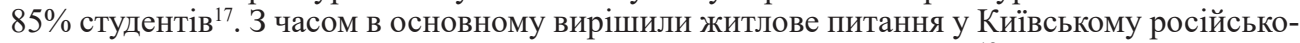
му ПТ. У 1930-1931 н.р. у гуртожитках проживали 50\% студентів ${ }^{18}$, у 1931-1932 н. р. $57,6 \%{ }^{19}$, у липні 1933 р. $-27,3 \%{ }^{20}$, у $1933-1934$ н. p. $-86,9 \%^{21}$, у $1934-1935$ н. p. $-85,2 \%{ }^{22}$.

Водночас, у 1933 р. у Нововітебському єврейському ПТ житло мали лише 34,1\% молоді ${ }^{23}$; Житомирському єврейському $-33,3 \%{ }^{24}$; Київському польському $-11,6 \%{ }^{25}$. Значні труднощі були також у Вінницькому єврейському ${ }^{26}$, Маріупольському грецькому ${ }^{27}$ і Одеському єврейському ПТ ${ }^{28}$.

У більшості закладів не дотримувалися санітарно-гігієнічного нормативу щодо житлової площі, яка в середньому припадала на одного студента (він упродовж десятиліття становив від 4,5 до $5 \mathrm{~m}^{229}$ ). Так, у вересні 1933 р. у Нововітебському єврейському ПТ цей показник становив $2 \mathrm{~m}^{2}$, Дніпропетровському російському $-3^{30}$, Проскурівському польському - у вересні 1934 р. - 3,331. Звісно, це було джерелом справедливих нарікань молоді. 
Через житло виникали гострі конфлікти із місцевими організаціями. Так, конфліктна ситуація щодо розселення першокурсників виникла у Київському російському ПТ. Восени 1930 р. у гуртожитку для них надали лише 20 місць, а прийом становив 120 осіб. 3 Київської райспоживінспекції з приводу цього повідомляли: «Приймайте студентів стільки, скільки ми вам даємо місць в гуртожитках, а не скільки визначає НКО». Через це керівництво технікуму вимушено розмістило щойно зарахованих у навчальному корпусі, де не було ні ліжок, ні матраців, і молодь змушена була спати на підлозі. Це призвело до того, що упродовж навчального року $40 \%$ студентів покинули навчання ${ }^{32}$.

Житлом для частини студентів ставали на законних підставах і навчальні корпуси, наприклад, у Маріупольському грецькому ПТ ${ }^{33}$. У цьому закладі через нестачу житлової площі у гуртожитках на одному ліжку спали по 3 студенти ${ }^{34}$.

Деякі гуртожитки були непристосовані для проживання і мали жахливий вигляд. Наприклад, у квітні 1932 р. дописувач газети «Радянська Волинь» П. Стемпківський, відвідавши гуртожиток Житомирського єврейського ПТ по вул. Мало-Чуднівська, стверджував: «Гуртожиток зовсім невпорядкований, у кімнатах брудно... Гуртожиток більше нагадує кладову, ніж житлове приміщення. У кімнатах - дуже тісно» ${ }^{35}$.

Частина студентів, яких не змогли забезпечити гуртожитком, подалися на приватні квартири («кутки»). Так, Проскурівський польський ПТ на приватних квартирах розмістив 20 студентів, сплачуючи за кожного з них по 10 руб. на місяць ${ }^{36}$. У Київському російському

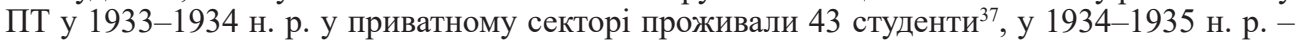
$39^{38}$, польському ПТ - у $1934-1935$ н. p.- $6^{39}$.

Більшість гуртожитків й у 1930-і рр. недостатньо були забезпечені меблями, не вистачало постільної білизни.

Таблиця № 1

Інформація про забезпечення студентів деяких педагогічних навчальних закладів національних меншин меблями і постільною білизною (1930-ті рр.)

\begin{tabular}{|c|c|c|c|c|c|c|c|c|c|c|}
\hline \multirow[b]{2}{*}{$\begin{array}{c}\text { Назви } \\
\text { навчальних } \\
\text { закладів }\end{array}$} & \multirow{2}{*}{ 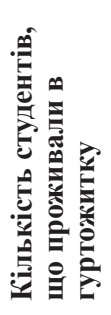 } & \multicolumn{4}{|c|}{$\begin{array}{c}\text { Забезпеченість } \\
\text { студентів меблями } \\
\text { (шт.) }\end{array}$} & \multicolumn{5}{|c|}{$\begin{array}{c}\text { Забезпеченість студентів } \\
\text { постільною білизною } \\
\text { (шт.) }\end{array}$} \\
\hline & & 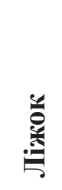 & $\stackrel{\oplus}{\stackrel{B}{g}}$ & 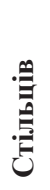 & 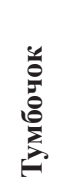 & 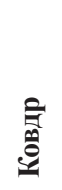 & 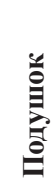 & 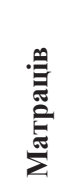 & 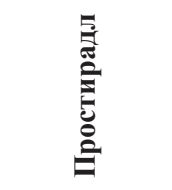 & 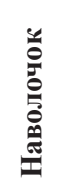 \\
\hline $\begin{array}{l}\text { Вінницький } \\
\text { єврейський ПТ } \\
\text { - 1934-1935 н. p. }{ }^{40} \\
\end{array}$ & 221 & 250 & $*$ & $*$ & 79 & 221 & * & 197 & 570 & 500 \\
\hline $\begin{array}{l}\text { Житомирський } \\
\text { єврейський ПТ } \\
-1933 \text { р.11 }\end{array}$ & 100 & $*$ & $*$ & $*$ & $*$ & 55 & $*$ & 70 & $*$ & 120 \\
\hline $\begin{array}{l}\text { Київський } \\
\text { польський ПТ } \\
-1934-1935 \text { н. p. }{ }^{42}\end{array}$ & 230 & 250 & $*$ & $*$ & 100 & $*$ & $*$ & $*$ & 750 & 500 \\
\hline $\begin{array}{l}\text { Київський } \\
\text { російський ПТ } \\
-1934-1935 \text { н. p.33 }\end{array}$ & 219 & 323 & 100 & $*$ & 118 & 300 & $*$ & 330 & 872 & $*$ \\
\hline $\begin{array}{l}\text { Маріупольський } \\
\text { грецький ПТ } \\
\text { - жовтень } 1933 \text { p. }^{44}\end{array}$ & $*$ & $*$ & $*$ & $*$ & $*$ & $*$ & $*$ & $*$ & $\begin{array}{c}\text { Забезпечено } \\
\text { на } 35 \%\end{array}$ & $*$ \\
\hline $\begin{array}{l}\text { Проскурівський } \\
\text { польський ПТ } \\
-1934-1935 \text { н. p. }{ }^{45}\end{array}$ & 164 & 190 & $*$ & $*$ & 100 & 183 & $*$ & 212 & 194 & 165 \\
\hline
\end{tabular}

* Даних не виявлено. 
Не вистачало постільної білизни також у Дніпропетровському російському, Нововітебському єврейському ${ }^{46}$ і Преславському болгарському ПТ ${ }^{47}$.

Для дотримання дисципліни в гуртожитках для студентів на засіданнях старостатів розробляли правила внутрішнього розпорядку, які поміщали в кожній кімнаті ${ }^{48}$. Зокрема, у Київському російському ПТ відповідно до таких правил у місцях проживання категорично заборонялося палити, викидати сміття в коридор, умивальники тощо, чистити взуття та витрушувати одяг, розпалювати примус, тримати різних тварин, мити посуд в умивальниках, викидати об їдки їжі, сміття у рукомийники і т. д. За дотриманням цих норм в гуртожитках встановлювалося чергування. Чергових призначав комендант. Студенти формували «трійки сприяння», які про всі «ненормальні явища» в житті гуртожитку і порушення цих правил мали негайно повідомляти адміністрацію педтехнікуму чи коменданта. Кожна кімната на півроку обирала свого старосту ${ }^{49}$.

Регулярно проводилися змагання між кімнатами. У Київському російському ПТ у 1934-1935 н. р. премії вибороли студенти, які у найкращому стані утримували три кімнати: їм надали шафи, килимки. 6 старост кімнат відзначили мануфактурою ${ }^{50}$. Переможці змагань Проскурівського польського ПТ отримували право на радіофікування їхніх кімнат $^{51}$. Крім того, їм видали по 2 комплекти простирадл ${ }^{52}$. Для проведення генерального прибирання гуртожитків організовували суботники, як правило, напередодні державних свят (наприклад, у Київському російському ПТ ${ }^{53}$ ).

За дотриманням чистоти і дисципліни в гуртожитках слідкували побутові та санітарні комісії, зокрема, у Проскурівському польському ПТ. Що стосується останніх, то вони проводили перевірку один раз на два тижні. У кожній кімнаті вели записи у санітарному зошиті, де санкомісія робила відмітки про санітарний стан кімнати ${ }^{54}$.

У гуртожитках відбувалися систематичні крадіжки, оскільки кімнати не зачинялися. У березні 1934 р. директор Проскурівського польського ПТ Домбровський звернувся із листом до Славутського районного адміністративного відділу, у якому просив розшукати і притягнути до судової відповідальності студента Е. Гептика за те, що той втік з технікуму, вкравши при цьому з гуртожитку 2 простирадла і 5 книжок ${ }^{55}$. Після звістки про ліквідацію цього закладу студенти намагалися прихопити з собою що-небудь 3 його майна. Так, студент П. Ословський забрав із собою ковдру, простирадло, матрац, наволочку, книжки. Справу передали до міліції ${ }^{56}$. За крадіжку майна віддали під суд і відрахували з Київського російського ПТ Лаптініна ${ }^{57} .3$ Преславського болгарського ПТ повідомляли, що через крадіжки змушені були звернутися до міліції, але вони не припинилися ${ }^{58}$.

Для запобігання крадіжкам та псування державного майна запровадили чергування студентів, під час якого вони несли за його збереження персональну відповідальність (наприклад, у Проскурівському польському ПТ) ${ }^{59}$.

Деяким студентам давали можливість реабілітуватися за вчинення правопорушення. Наприклад, у жовтні 1933 р. на засіданні директорату Київського російського ПТ розглянули заяву студентки німецького сектора Штеймнець про скасування постанови загального показового громадського суду, який ухвалив відрахувати іiї за крадіжку. Вона просила дати їй шанс виправитися, щоби в подальшому стати зразковою студенткою. Керівництво закладу ухвалило піти їй на зустріч, встановивши випробувальний термін у два місяці ${ }^{60}$.

Значною проблемою студентських гуртожитків було заселення їх особами зі сторони, які іноді займали значну частину площі. Зокрема, безпідставно заселяли сторонніх осіб у помешкання Дніпропетровського російського ПТ ${ }^{61}$. Для врегулювання таких ситуацій було прийнято навіть спеціальну постанову ВУЦВК від 12 червня 1929 р., проте виконати іiі часом не було ніякої можливості ${ }^{62}$.

У 1930-ті рр. вдалося радіофікувати більшість гуртожитків, зокрема, Житомирського єврейського ${ }^{63}$, київських польського ${ }^{64}$ і російського ПТ ${ }^{65}$.

У гуртожитках першочергової ваги надавали питанням санітарної обробки, т. зв. «санмінімуму». Зокрема, у Київському російському ПТ він передбачав, що натільна білизна мала змінюватися щодекадно, а постільна - 2 рази на місяць; хворі повинні були перебувати в ізоляторі. Підлоги передбачалося мити 1 раз у 3 дні, а на верхньому поверсі - 1 раз у 5 днів. Примуси дозволялося запалювати лише на кухні. Заборонялося в кімнатах палити, прати білизну і сушити тощо ${ }^{66}$. 
Складнощі виникали із забезпеченням студентів лазнями. Для надання молоді таких послуг більшість закладів змушені були укладати угоди з міськими лазнями, які робили студентам певні знижки. Студенти Київського російського ${ }^{67}$, Київського $^{68}$ і Проскурівського польських ПТ відвідували лазню один раз на 10 днів ${ }^{69}$. Педтехнікуми відчували також і нестачу пралень. За нашими даними, вони запрацювали переважно 3 30-х pp. XX ст., зокрема у Житомирському єврейському (3 1934 р. $)^{70}$, Проскурівському польському ПТ ${ }^{71}$.

Частині студентів виплачували державні стипендії, розмір яких був мізерним. Їх не вистачало навіть на придбання найнеобхіднішого. Стипендіїнадавалися не на основі академічної успішності, а на засадах принципу соціального походження студента. Першочергово ними забезпечувалися комуністи, випускники робітфаків, робітничоселянський прошарок молоді. У 1925-1926 н. р. у Житомирському єврейському ПТ державні стипендії отримували 32 студенти, що становило 40\% від загальної кількості молодi $^{72}$, київських російському - відповідно 40 і 24,2\%, єврейському - 64 і 50,3\%, польському, 70 і 68,6\% ${ }^{73}$, Одеському єврейському - 110 і 78,6\% ${ }^{74}$; Вінницькому єврейському - у 1927-1928 н. p. -61 i 30\%, у 1929-1930 н. p. - 80 і 39,475; Дніпропетровському російському - у 1927-1928 н. p. - 45 і 33,1\%. В останньому виші у 1928-1929 н. р. стипендіальне за-

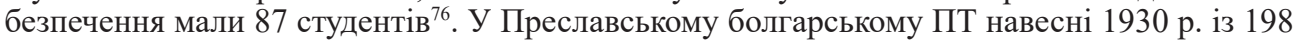
студентів денної форми навчання допомогу отримували 90 (45,5\% від загальної чисельності $)^{77}$. У 1931 р. у київських польському ${ }^{78}$ і російському ${ }^{79}$ стипендії мали $55 \%$ студентів ${ }^{80}$.

Мали місце випадки, коли допомоги повністю не виплачувалися, і вони подрібнювалися. Завдяки цьому вдалося, хоч би мінімально, забезпечити запити студентів, більшість 3 яких були вихідцями з робітників і незаможних селян. Подібне мало місце у Вінницькому єврейському ПТ ${ }^{81}$.

Студенти педтехнікумів нацменшин, які прибували на навчання з різних регіонів, особливо потребували стипендій. Зокрема, 21 грудня 1930 р. під час наради, на якій обговорювали становище Київського польського ПТ, звернули увагу на вищезазначену обставину. Писутні заявили, що в умовах Києва молодь без стипендії не зможе навчатися. Через матеріальні труднощі восени того ж року з 83 новоспечених першокурсників залишилося лише 43. Тому пропонували відсоток забезпечення стипендією збільшити до 85, для чого ухвалили звернутися до РНК УСРР. У резолюції вказувалося, що у такому ж становищі знаходиться студентство й інших національних педтехнікумів ${ }^{82}$. Невдовзі становище вдалося змінилося на краще.Так, у Київському російському ПТ у 1932 н. р. стипендії отримували $85,4 \%$ студентів ${ }^{83}$, у першому семестрі $1934-1935$ н. р. $-99,3 \%^{84}$. У $1934-1935$ н. р. 100-відсотково забезпечили стипендіями студентів Проскурівського польського ПТ ${ }^{85}$. В українських педтехнікумах ці показники були скромнішими.

Частина стипендій фінансувалися з бюджетів місцевих органів державної влади. Наприклад, у Вінницькому єврейському ПТ наприкінці березня 1928 р. такі стипендії отримували 4 студенти (по 10 руб.), у 1929-1930 н. р. - 2086;

На початку 1920-х рр., незважаючи на важке матеріальне становище студентства, запровадили плату за навчання. Вона була введена як «тимчасова міра, як засіб для піддержки господарського добробуту шкільних закладів» ${ }^{87}$. Ї̈̈ стягували 3 усіх соціальних категорій населення, у т.ч. робітників і селян, що відчутно вдарило по їх бюджету. Частині 3 них надали пільги по сплаті. Щоб вижити, студенти-нестипендіати змушені були шукати заробітку і заробляти гроші на проживання, проплату за навчання, часто пропускаючи заняття. На жаль, даних про внесення плати студентами педтехнікумів нацменшин обмаль. Відомо лише, що у 1925-1926 н. р. у Житомирському єврейському ПТ платили 7,05\% молоді ${ }^{88}$. Такі кроки влади не додавало студентам оптимізму і впевненості у правильному виборі професії, сіяло у їхньому середовищі настрої зневіри і апатії.

Складно було забезпечити студентів нормальним харчуванням, особливо у 1920-ті pp. Важке повсякденне життя призводило до того, що частина молоді змушена була кидати навчання. 25 листопада 1924 р. на засіданні малої президії ВУЦВК йшлося про важке становище. Тому учасники зібрання пропонували НКО спільно з Наркоматом харчування розробити проект організації дешевих їдалень для студентів ${ }^{89}$. Подальші події показали, що реального покращення, на жаль, не відбулося. У 1926 р. в журналі «Комсомолець-агітатор» зазначалося: «Матеріальне положення студентства дуже погане, майже не покращується, не зважаючи на розвиток нашого господарства» ${ }^{90}$. У 1928 р. голова 
Укрголовпрофосвіти Я. Ряппо визнав, що нормальних умов для навчання студентства тоді ще не було ${ }^{91}$. Це стосувалося і більшості педагогічних навчальних закладів. Наприклад, Преславський болгарський через матеріальну незабезпеченість у 1929-1930н. р. покинули 23 студенти ${ }^{92}$.

На початку 1930-х рр. почали виникати перебої з постачанням молоді хлібом. 3 Преславського болгарського ПТ били тривогу, що у 1931 р. були випадки, коли студенти по 2-3 дні сиділи без хліба. 5 січня 1932 р. через його відсутність молодь відпустили додому на 10 днів. У лютому-березні того ж року такі випадки повторювалися через кожних 5-7 днів ${ }^{93}$.

Не оминув студентство Голодомор 1932-1933 pp. Вже навесні 1932 р. фактично удвічі зменшили норму видачі хліба. Взимку молодь Преславського болгарського ПТ отримувала лише 200-300 г хліба ${ }^{94}$. Водночас, навіть цієї мізерної пайки чекали по 2-3 дні У січні 1933 р. студентство Маріупольського грецького ПТ на хліб очікувало 4 дні ${ }^{95}$. У Калінініндорфському єврейському ПТ на весь день студентам видавали по 100-180 г крупи ${ }^{96}$. Порівняно кращим було становище у Хортицькому німецькому ПТ, де наприкінці 1932 p. студентам видавали 400 г хліба ${ }^{97}$. Становище переважної частини молоді добре відбиває заява одного із студентів Проскурівського польського ПТ, який просив надати йому позику в розмірі 10 руб., яку зобов`язувався повернути зі стипендії, бо йому просто не було за що харчуватися ${ }^{98}$.

У $1932-1933$ рр. зросла вартість харчування для студентської молоді педагогічних навчальних закладів. Так, студентство Житомирського єврейського ПТ харчувалося за 1 руб. 30 коп. в день ${ }^{99}$.

Незадовільне харчування штовхало молодь до вчинення дрібних злочинів. Наприклад, частина молоді Проскурівського польського ПТ підхарчовувалася в саду військкомату, що знаходився поряд з технікумом. Кількох студентів зловили і віддали до райвідділу міліції ${ }^{100}$.

Становище студентства почало поліпшуватися лише з середини 1930-х рр. У порівнянні з 1932-1933 рр. їжа була більш калорійною, але все ще недостатньою 3 погляду фізіологічних потреб. Так, у Проскурівському польському ПТ, у їдальні якого у вересні 1934 р. харчувалося 216 студентів ${ }^{101}$, калорійність спожитих продуктів становила 1300 ккал на добу, 645 ккал з яких приходилися на обід ${ }^{102}$. Низькою була калорійність їжі у Київському російському ПТ ${ }^{103}$.

Студентам-випускникам і ударникам організовувалися покращені обіди. У Київському російському ПТ у 1935 р. за власний рахунок під час випускного вечора організували для випускників вечерю з трьох страв ${ }^{104}$.

У міжвоєнний період поряд із недостатнім забезпеченням продуктами, бракувало також взуття і одягу, товарів широкого вжитку, державне постачання яких було вкрай недостатнім. Особливо скрутно було 3 взуттям. Так, у Київському російському ПТ у 1934-1935 н. р. на 292 студенти видали 20 пар черевиків ${ }^{105}$. У 1934 р. в Проскурівському польському ПТ взуття отримали понад 70 студентів (близько 50\% від загальної кількості молоді ${ }^{106}$. Один із студентів закладу просив надати йому триденну відпустку в зв язку 3 тим, що в нього порвалися чоботи, а відремонтувати їх він не має можливості. Купити черевики в нього не було грошей, тому кілька днів до цього ходив босим. Він просив дирекцію дозволу поїхати у село, щоб там йому відремонтували взуття, і він таким чином міг продовжити навчання. Як правило, керівництво такі заяви задовольняло ${ }^{107}$.

Вкрай недостатнім було державне постачання одягу. Так, у 1934-1935 н. р. на всіх студентів Київського російського ПТ виділили лише 8 пальто, 10 напівпальто, тканину на сорочки і плаття ${ }^{108}$. За таких умов стимулювати навчальну працю студентства було справою вельми складною.

Загалом, відсутність належної турботи про майбутніх педагогів, погане харчування, забезпечення гуртожитками, недостатній рівень фінансової допомоги призвели до великого відсіву молоді, шо викликало загрозу підготовки кадрів для шкіл республіки. Так, у 1925-1926 н. р. студентський контингент Житомирського єврейського ПТ скоротився на $24,7 \%{ }^{109}$, Проскурівському польському - в $1931-1932$ н. p. $-19 \%{ }^{110}$, Київському російському - у $1932-1933$ н. р. - понад $50 \%{ }^{111}$, у $1934-1935$ н. р. $-33,6 \%{ }^{112}$, польському $-19,4 \%{ }^{113}$. Звідси, незважаючи на декларативні заяви влади про важливу роль студентів - майбутні- 
хучителів у державному будівництві, ій так і не вдалося задовольнити на належному рівні їхні матеріальні проблеми.

Таким чином, у 20-30-ті pp. XX ст. для більшості педтехнікумів були характерними нестача навчальних приміщень, гуртожитків, насамперед, у 1920-ті рр., що пояснювалося повоєнною руїною. Деякі виші мали житлові приміщення, частина з яких були непристосовані для проживання. Зокрема, житлом для частини студентів ставали навчальні корпуси. Існували чималі труднощі із забезпеченням студентських помешкань меблями та постільною білизною. Внутрішній розпорядок у гуртожитках регулювали правила проживання. Щоправда, їх не завжди дотримувалися: хронічними «хворобами» були систематичні крадіжки, заселення гуртожитків сторонніми особами. Більшість гуртожитків не мали власних лазень і пралень. Частину студентів забезпечували стипендіями, розмір яких був мізерний. Студенти педтехнікумів нацменшин, які прибували на навчання 3 різних регіонів, особливо їх потребували. Водночас, більшовики, порушивши свій принцип про безкоштовність освіти, на початку 1920-х рр. запровадили плату за навчання, що погіршило матеріальне становище майбутніх педагогів. Чимало труднощів виникало із забезпеченням студентства харчуванням, особливо під час голодомору 1932-1933 рр. У 1920 30-ті pр. поряд із недостатнім забезпеченням продуктами, бракувало також взуття і одягу.

${ }^{1}$ Липинський В. В. Становлення і розвиток нової системи освіти в УСРР у 20-і роки: монографія. Донецьк: РВА Донецьк. держ. техн. ун-т, 2000. С. 84.

${ }^{2}$ Липинский В. В. Кто защитит студента? Студенческие организации Украины: история и современность. Донецк: редакц.-издат. отдел Донецк. управл. по печати, 1991. 116 с.

${ }^{3}$ Рябченко О. Студенти радянської України 1920-1930-х років: практики повсякденності та конфліктиідентифікації. Харків: ХНАМГ, 2012. 456 с.; Ї̈ ж. Житлові умови студентів радянської України у 1920-1930-ті роки // Наукові праці історичного факультету Запорізького національного університету / [редкол.: Ф. Г. Турченко (гол. ред.), Г. М. Васильчук, О. М. Ігнатуша та ін.]. Запоріжжя: Запоріз. нац. ун-т, 2013. Вип. XXXVI. С. 134-140.

4 Чирко Б. В. Національні меншини в Україні (20-30 роки XX століття). Київ: Асоціація «Україна», 1995. $215 \mathrm{c}$

${ }^{5}$ Шевчук Г. М. Культурне будівництво на Україні у 1921-1925 роках. Київ: вид-во АН УРСР, $1963.436 \mathrm{c}$.

${ }^{6}$ Гринько А. I. Вищі навчальні заклади Хмельниччини в роки голодомору 1932-1933 pp. // Освіта, наука і культура на Поділлі: зб. наук.пр. / [редкол.: П. Т. Тронько (гол.), О. М. Завальнюк (відп. ред.), Л. В. Баженов та ін.]. Кам'янець-Подільський: Оіюм, 2007. Т. 9. С. 287-300; Його ж. Діяльність закладів середньо-спеціальної, професійно-технічної та партійної освіти Хмельниччини під час голодомору 1932-1933 р. // Там само. Т. 10. С. 307-321.

${ }^{7}$ Міменко I. В. Проскурівський польський педагогічний технікум (1932-1935рр.) // Краєзнавець Хмельниччини: наук.-краєзнавч. зб. / [редкол.: Л. В. Баженов (гол.), С. Е. Баженова, О. П. Григоренко та ін.]. Кам'янець-Подільський: Сисин О. В., 2011. С. 129-137; Ї̈ ж. Студентство Проскурівського польського педагогічного технікуму (30-ті pp. XX ст.) // Вінниччина: минуле та сьогодення (краєзнавчі дослідження): матеріали XXV всеукр. наук. іст.-краєзнавч. конф., м. Вінниця, 11-12 жовтня 2013 р. / [редкол.: Ю. А. Зінько (відп. ред.), А. В. Войнаровський, Л. М. Спірідонова та ін.]. Вінниця: Вінниц. держ. пед. ун-т ім. М. Коцюбинського, 2013. С. 428-431.

${ }^{8}$ Шевчук Г. М. Культурне будівництво. С. 291-292.

${ }^{9}$ Центральний державний архів вищих органів влади і управління України (далі - ЦДАВО України). Ф. 166. Оп. 10. Спр. 1495. Арк. 67.

${ }^{10}$ Державний архів (далі - Держархів) Вінницької обл. Ф. П. 457. Оп. 6. Спр. 447. Арк. 31.

${ }_{11}$ Держархів Вінницької обл. Ф. П. 29. Оп. 1. Спр. 422. Арк. 47; Спр. 620. Арк. 101; Ф. Р. 595. Оп. 2. Спр. 306. Арк. 139, 252.

${ }^{12}$ Держархів Житомирської обл. Ф. Р. 266. Оп. 1. Спр. 167. Арк. 219; Єврейський педагогічний технікум // Житомирський вісник: інформ.-рекламн. тижневик Житомир. обл. орг. Спілки журналістів України. Житомир, 1990. 20 лип.

${ }^{13}$ Центральний державний архів громадських об'єднань України (далі - ЦДАГО України). Ф. 1. Оп. 20. Спр. 2930. Арк. 32.

${ }^{14}$ ЦДАГО України. Ф. 1. Оп. 20. Спр. 2010. Арк. 76.

${ }^{15}$ Держархів Житомирської обл. Ф. Р. 266. Оп. 1. Спр. 167. Арк. 228.

${ }^{16}$ ЦДАВО України. Ф. 166. Оп. 11. Спр. 326. Арк. 26.

${ }^{17}$ Держархів Хмельницької обл. Ф. Р. 2597. Оп. 1. Спр. 7. Арк. 9.

${ }_{18}$ Держархів м. Києва. Ф. Р. 359. Оп. 1. Спр. 11. Арк. 11. 
${ }^{19}$ Там само. Спр. 44. Арк. Ззв.; ЦДАВО України. Ф. 166. Оп. 10. Спр. 1490. Арк. 43-44.

${ }^{20}$ ЦДАВО України. Ф. 166. Оп. 11. Спр. 329. Арк. 26.

${ }_{21}$ Держархів м. Києва. Ф. Р. 359. Оп. 1. Спр. 67. Арк. 42.

${ }_{22}^{2}$ Там само. Спр. 135. Арк. 26; Спр. 137. Арк. 8.

${ }^{23}$ Держархів Хмельницької обл. Ф. Р. 300. Оп. 1. Спр. 53. Арк. 28.

${ }^{24}$ ЦДАВО України. Ф. 166. Оп. 11. Спр. 326. Арк. 68.

${ }^{25}$ Там само. Спр. 329. Арк. 26.

${ }_{26}$ Держархів Вінницької обл. Ф. П. 457. Оп. 1. Спр. 437. Арк. 7; Спр. 447. Арк. 72; Держархів Хмельницької обл. Ф. Р. 300. Оп. 1. Спр. 53. Арк. 24.

${ }^{27}$ Держархів Хмельницької обл. Ф. Р. 300. Оп. 1. Спр. 53. Арк. 24.

${ }^{28}$ ЦДАВО України. Ф. 166. Оп. 10. Спр. 798. Арк. 10.

${ }^{29}$ Держархів Хмельницької обл. Ф. Р. 2597. Оп. 1. Спр. 5. Арк. 24зв.; Міщенко І. В. Умови навчання та проживання. С. 40.

${ }^{30}$ Держархів Хмельницької обл. Ф. Р. 300. Оп. 1. Спр. 53. Арк. 28.

31 Там само. Ф. Р. 2597. Оп. 1. Спр. 7. Арк. 107.

${ }^{32}$ ЦДАВО України. Ф. 166. Оп. 10. Спр. 1490. Арк. 40-40зв.

${ }^{33}$ ЦДАВО України. Ф. 166. Оп. 10. Спр. 814. Арк. 73.

${ }^{34}$ Там само. Оп. 11. Спр. 326. Арк. 9.

${ }_{35}$ Степківський П. Санітарний стан гуртожитків євпедтехнікуму незадовільний // Радянська Волинь. Житомир, 1932. 19 квіт.

${ }^{36}$ Держархів Хмельницької обл. Ф. Р. 2597. Оп. 1. Спр. 1. Арк. 262.

37 Держархів м. Києва. Ф. Р. 359. Оп. 1. Спр. 67. Арк. 42.

38 Там само. Спр. 135. Арк. 26; Спр. 137. Арк. 8.

${ }^{39}$ Там само. Ф. Р. 807. Оп. 11. Спр. 18. Арк. 26.

40 Держархів Вінницької обл. Ф. П. 457. Оп. 1. Спр. 437. Арк. 8, 33; Спр. 447. Арк. 32-33.

${ }^{41}$ ЦДАВО України. Ф. 166. Оп. 11. Спр. 329. Арк. 26.

${ }^{42}$ Держархів м. Києва. Ф. Р. 807. Оп. 11. Спр. 18. Арк. 27.

${ }^{43}$ Там само. Ф. Р. 359. Оп. 1. Спр. 135. Арк. 26.

${ }^{44}$ Держархів Хмельницької обл. Ф. Р. 300. Оп. 1. Спр. 53. Арк. 24.

${ }^{45}$ Там само. Ф. Р. 2597. Оп. 1. Спр. 6. Арк. 3; Спр. 7. Арк. 107.

${ }^{46}$ Держархів Хмельницької обл. Ф. Р. 300. Оп. 1. Спр. 53. Арк. 28.

${ }^{47}$ ЦДАВО України. Ф. 166. Оп. 10. Спр. 825. Арк. 6.

48 Держархів Вінницької обл. Ф. П. 292. Оп. 1. Спр. 24. Арк. 1.

49 Держархів м. Києва. Ф. Р. 359. Оп. 1. Спр. 205. Арк. 2, $5,7$.

${ }^{50}$ Там само. Спр. 135. Арк. 27.

${ }^{51}$ Держархів Хмельницької обл. Ф. Р. 2597. Оп. 1. Спр. 6. Арк. 3.

52 Там само. Арк. 5.

53 Держархів м. Києва. Ф. Р. 359. Оп. 1. Спр. 69. Арк. 21зв.

54 Держархів Хмельницької обл. Ф. Р. 2597. Оп. 1. Спр. 6. Арк. 3; Спр. 7. Арк. 107.

55 Там само. Спр. 1. Арк. 87.

${ }^{56}$ Міщенко I. В. Проскурівський польський педагогічний технікум. С. 133-134; Ï̈ ж. Студентство Проскурівського польського педагогічного технікуму. С. 431.

57 Держархів м. Києва. Ф. Р. 359. Оп. 1. Спр. 135. Арк. 23.

${ }^{58}$ ЦДАВО України. Ф. 166. Оп. 10. Спр. 825. Арк. 6.

59 Держархів Хмельницької обл. Ф. Р. 2597. Оп. 1. Спр. 1. Арк. 253.

${ }^{60}$ Держархів м. Києва. Ф. Р. 359. Оп. 1. Спр. 61. Арк. 34.

${ }^{61}$ Держархів Хмельницької обл. Ф. Р. 300. Оп. 1. Спр. 53. Арк. 28.

${ }_{62}$ Рябченко О. Студенти радянської України 1920-1930-х років: практики повсякденності та конфліктиідентифікації. Харків: ХНАМГ, 2012. С. 343.

${ }^{63}$ ЦДАГО України. Ф. 7. Оп. 1. Спр. 1079. Арк. 255.

${ }^{64}$ Держархів м. Києва. Ф. Р. 807. Оп. 11. Спр. 18. Арк. 27.

${ }^{65}$ Там само. Ф. Р. 359. Оп. 1. Спр. 67. Арк. 96.

${ }^{66}$ Там само. Спр. 205. Арк. 1.

${ }^{67}$ Там само. Спр. 67. Арк. 42, 97; Спр. 135. Арк. 25.

${ }^{68}$ Там само. Ф. Р. 807. Оп. 11. Спр. 18. Арк. 26.

${ }^{69}$ Держархів Хмельницької обл. Ф. Р. 2597. Оп. 1. Спр. 1. Арк. 253зв.; Спр. 6. Арк. 3.

70 Держархів Житомирської обл. Ф. П. 215. Оп. 1. Спр. 2. Арк. 7.

${ }^{71}$ Держархів Хмельницької обл. Ф. Р. 2597. Оп. 1. Спр. 1. Арк. 253зв.; Спр. 6. Арк. 3.

72 Держархів Житомирської обл. Ф. Р. 266. Оп. 1. Спр. 142. Арк. 19зв.

${ }^{73}$ ЦДАВО України. Ф. 166.Оп. 5. Спр. 628. Арк. 79зв.

${ }^{74}$ Там само. Спр. 264. Арк. 66.

75 Держархів Вінницької обл. Ф. П. 29. Оп. 1. Спр. 620. Арк. 101.

76 Держархів Дніпропетровської обл. Ф. П. 7. Оп. 1. Спр. 1489. Арк. 47, 126. 
${ }^{77}$ ЦДАВО України. Ф. 166. Оп. 10. Спр. 825. Арк. 150.

${ }^{78}$ Там само. Оп. 9. Спр. 787. Арк. 7.

79 Там само. Оп. 10. Спр. 1490. Арк. 40; Держархів м. Києва. Ф. Р. 359. Оп. 1. Спр. 11. Арк. 11.

${ }^{80}$ ЦДАВО України. Ф. 166. Оп. 9. Спр. 1783. Арк. 32.

${ }^{81}$ Держархів Вінницької обл. Ф. П. 29. Оп. 1. Спр. 414. Арк. 18.

${ }_{82}$ Там само. Спр. 787. Арк. 1-3.

${ }^{83}$ Держархів м. Києва. Ф. Р. 359. Оп. 1. Спр. 44. Арк. Ззв.

${ }^{84}$ Там само. Спр. 137. Арк. 1зв.

${ }^{85}$ Держархів Вінницької обл. Ф. П. 457. Оп. 1. Спр. 444. Арк. 156.

${ }^{86}$ Там само. Ф. П. 29. Оп. 1. Спр. 414. Арк. 18; Спр. 620. Арк. 101.

${ }^{87}$ Держархів Хмельницької обл. Ф. Р. 302. Оп. 1. Спр. 385. Арк. 15.

88 Держархів Житомирської обл. Ф. Р. 266. Оп. 1. Спр. 142. Арк. 193 в.

${ }^{89}$ ЦДАВО України. Ф. 2. Оп. 3. Спр. 209. Арк. 5.

${ }^{90}$ Липинский В. В. Кто защитит студента. С. 8.

${ }^{91}$ Ряппо Я. Радянське студентство (характеристика вузів України). Харків: Держ. вид-во Укр., 1928. C. 39 .

${ }_{92}^{2}$ ЦДАВО України. Ф. 166. Оп. 10. Спр. 825. Арк. 150.

${ }^{93}$ Там само. Арк. 65-65зв.

${ }^{94}$ Там само. Арк. 8.

95 Там само. Оп. 11. Спр. 326. Арк. 9.

${ }^{96}$ Там само. Арк. 1.

${ }^{97}$ Чирко Б. В. Національні меншини в Україні. С. 108.

${ }^{98}$ Гринько А. І. Діяльність закладів. С. 315.

${ }^{99}$ ЦДАВО України. Ф. 166. Оп. 11. Спр. 326. Арк. 69.

${ }^{100}$ Гринько А. І. Діяльність закладів. С. 315.

101 Держархів Хмельницької обл. Ф. Р. 2597. Оп. 1. Спр. 7. Арк. 105.

${ }^{102}$ Там само. Спр. 6. Арк. 5.

103 Держархів м. Києва. Ф. Р. 359. Оп. 1. Спр. 67. Арк. 42.

${ }^{104}$ Там само. Спр. 135. Арк. 26.

${ }^{105}$ Там само. Арк. 27.

106 Держархів Хмельницької обл. Ф. Р. 2597. Оп. 1. Спр. 3. Арк. 14.

${ }^{107}$ Гринько А. І. Діяльність закладів. С. 315.

108 Держархів м. Києва. Ф. Р. 359. Оп. 1. Спр. 135. Арк. 27.

109 Держархів Житомирської обл. Ф. Р. 266. Оп. 1. Спр. 142. Арк. 16зв.

110 Держархів Хмельницької обл. Ф. Р. 2597. Оп. 1. Спр. 2. Арк. 57.

111 Держархів м. Києва. Ф. Р. 359. Оп. 1. Спр. 67. Арк. 82.

112 Там само. Спр. 135. Арк. 3; Спр. 135. Арк. 1.

${ }^{113}$ Там само. Ф. Р. 807. Оп. 11. Спр. 18. Арк. 1. 